Article

\title{
Narratives of Social Inclusion in the Context of Roma School Segregation
}

\author{
Helen O’Nions \\ Law School, Nottingham Trent University, Nottingham, NG1 4BU, UK; E-Mail: helen.onions@ntu.ac.uk
}

Submitted: 16 March 2015 | In Revised Form: 8 May 2015 | Accepted: 20 May 2015 |

Published: 29 September 2015

\begin{abstract}
Despite a series of judgements from the European Court of Human Rights and the enactment of the EU Racial Equality Directive, the educational segregation of Roma pupils persists in several European states. State action plans submitted pursuant to the European Framework for Roma Integration rarely provide clear targets and do not commit to inclusive schooling. Taking education as a principle indicator of social inclusion, this article identifies that structural inequality and entrenched discriminatory attitudes are the main obstacles to Roma inclusion. This can only be addressed through the diffusion of legal and social norms that mainstream equality. Focusing on the legal obligations, it is argued that the European Commission must be more decisive and effective in the enforcement of non-discrimination rules. A closer dialogue between the European Court of Human Rights and the EU institutions, grounded in a non-targeted social inclusion frame, could provide a platform for European consensus which may help to secure meaningful change.
\end{abstract}

\section{Keywords}

children; discrimination; education; Europe; exclusion; integration; law; Roma; school; segregation

\section{Issue}

This article is part of the special issue "Talking about Roma: Implications for Social Inclusion", edited by Dr. Eben Friedman (Independent Consultant and Senior Non-resident Research Associate, European Centre for Minority Issues, Germany).

(C) 2015 by the author; licensee Cogitatio (Lisbon, Portugal). This article is licensed under a Creative Commons Attribution 4.0 International License (CC BY).

\section{Introduction}

Education is one of the fundamental measures of social inclusion. Equality in education is essential to the realisation of all other social inclusion indicators, such as employment, healthcare and poverty reduction. Further, unlike the other indicators, the right to education has a discrete international legal basis that establishes particular parameters against which it becomes comparatively easy to measure a state's commitment to inclusion.

As a starting point we can assert that an inclusive education should be free from discrimination but the development of legal principles in this area has come to mean much more than this. The judgements of the European Court of Human Rights (hereafter "ECtHR") have moved from a relatively cautious endorsement of integrated education to an implicit expectation that states adopt positive measures to address disparities in educational access and attainment where such dispari- ties arise from discriminatory practices. Further it is probable that the separate education of Roma pupils (either in separate schools or classes) will be deemed unlawful, even when educators present separation as a remedial solution for educational disadvantage.

This article will begin by considering the adoption of education as a key measure of social inclusion and identify some of the challenges that the data reveals in terms of the educational experience of Roma pupils. The persistence of discriminatory educational provision needs to be viewed in the light of the legal standards established by the ECtHR since the seminal decision of $D H$ in 2007. It is argued that the persistence of such practices can only be explained by reference to deeprooted, discriminatory attitudes where Roma are regarded as less-deserving, "second class citizens" (Hammarberg, 2011). These attitudes need to be urgently addressed if social inclusion is to be more than empty rhetoric. 
One way of assessing a Member State's commitment to integrated education and social inclusion for the Roma is to examine the national action plans submitted pursuant to the EU Framework for National integration Strategies (European Commission, 2011). When commitments to desegregation are not prioritised conclusions may be drawn about the national government's commitment to inclusion. In such instances, the dialogical approach of the open method of coordination which characterises European social policy may be accused of lacking teeth. Here it will be argued that the European institutions need to draw on legally binding non-discrimination provisions and the judgements of the ECtHR to forge a European consensus which centres on mainstreaming equality and inclusion (Kocze et al., 2014).

Two recent developments suggest that a defined EU position is emerging. The Commission's decision to commence proceedings against the Czech Republic along with the Council's recommendation that Roma integration needs to be improved are indicative of a more robust approach (European Council, 2013). This will be an important step in the move from social inclusion as a broad, policy umbrella towards legally enforceable obligations grounded in the EU Charter of Fundamental Rights, the Racial Equality Directive and the judgements of the ECtHR. As the lessons from the Decade for Roma Inclusion (hereafter "roma Decade") suggest, legal obligations are an essential ingredient for norm diffusion which must be viewed as fundamental to ensuring Roma inclusion (Uzunova, 2010). It is submitted that success requires, inter alia, active engagement of Roma stakeholders but must also avoid the pitfalls of specifically targeting Roma as a "special" case emphasising difference at the expense of equality.

\section{Education as an Indicator of Inclusion}

The relationship between social inclusion and educational integration is palpable. Put simply, there can be no social inclusion where a significant number of pupils from one ethnic group are isolated from the mainstream education system. The application of other inclusion measures, particularly employment, becomes incoherent when more than $60 \%$ of pupils from one ethnic group do not complete secondary education (as is the case in all twelve of the central and southeastern European countries surveyed in 2011, see Brügemann, 2012).

Discrimination in education is prohibited by numerous international instruments, including the UNESCO Convention on Discrimination in Education; the UN International Convention on the Elimination of All forms of Racial Discrimination and the Convention on the Rights of the Child (UNESCO, 1960; United Nations, 1965; United Nations, 1989). The EU institutions and the Council of Europe have long been concerned about disparities in educational access and attainment between Roma and non-Roma pupils (O'Nions, 2015).

Under European law, non-discrimination is a founding value of the European Union and the Union is tasked with combating discrimination and social exclusion (European Council, 2012, Art. 2 and 3). The treaty articles are given effect by the Racial Equality Directive which prohibits direct and indirect discrimination as well as harassment in the field of education. Indirect discrimination occurs when an apparently neutral provision, criterion or practice puts persons of a particular racial group at a comparable disadvantage. States may provide an objective justification for indirectly discriminatory treatment (European Council, 2000, Art.2 (2b)). Article 5 provides that special measures "can" be enacted to "prevent or compensate for disadvantage" linked to race or ethnic origin. It is worth noting that an unusually large number of Member States faced difficulties implementing the Directive prior to the initial transposition deadline, leading the Commission to extend the original date. The obligations necessitated the enactment of new anti-discrimination laws and equality bodies in many states where there was no existing legal obligations (EU Fundamental Rights Agency, 2011). The Directive has thus been important in establishing legal expectations in societies where discriminatory practices had previously gone unchecked. The scale of the task cannot be overstated. Although all Member States have since been assessed as having made the required legal adjustments (European Commission, 2014c), the diffusion of anti-discrimination norms is a much longer process.

The Europe 2020 initiative priorities education with a view to reducing the rate of early school leaving to below $10 \%$ and ensuring that at least $40 \%$ of $30-34$ year-olds have completed "third-level" or higher education (European Council, 2009). These are certainly ambitious targets but they become particularly demanding when the education of Roma pupils is considered. The UN Development Programme has identified that in several European states over $80 \%$ of Roma are classed as early school leavers, having not completed a secondary level education. In some states, including the Czech Republic, Romania and Slovakia this rises to over $90 \%$ (Brügemann, 2012, p. 49). The same study found that computer literacy for Roma pupils was less than $50 \%$ in eleven countries surveyed, compared to a national average of over $80 \%$ (p. 28).

Whilst these figures are alarming they demand long-term, multi-faceted measures which go beyond the classroom to tackle questions of access including residential isolation, school transportation and parental attitudes (both Roma and non-Roma). There is no simple quick-fix solution. However, it is widely acknowledged that any solution depends on an integrated, inclusive school environment.

Yet a significant number of Roma children continue 
to receive an education where they are separated from their non-Rom peers. The Open Society (2011, p. 71) have observed that school segregation is the biggest social inclusion challenge facing urban Roma communities in Bulgaria. In Slovakia 43\% of Roma attend classes with a predominately Roma student body (compared to only $5 \%$ of non-Roma who live in close proximity to Roma neighbourhoods) and more than $20 \%$ of Roma children attend such schools in Hungary and Romania (Brügemann, 2012, p. 54). The extent of segregation in countries with relatively small Roma populations where integration should be easier to achieve is particularly noticeable. This includes the Czech Republic, Albania and Moldova-the latter has a Roma population comprising fewer than $3 \%$ of the general population but every third Roma child attends a Roma majority school (p. 65). Separation in special or practical schools designed for pupils who are deemed unable to cope with the rigors of mainstream schooling, remains common in many central and east European states. Over $60 \%$ of Roma in the Czech Republic and Slovakia attending these schools experience two-fold discrimination as the majority of pupils are also Roma (p. 71).

The European Commission quickly identified segregation as a particular challenge for Europe 2020 when it embarked on an EU Framework for Roma Integration Strategies (European Commission, 2011). Education is one of four policy objectives under the Framework and the Commission has made several pertinent observations:

Member States should ensure that all Roma children have access to quality education and are not subject to discrimination or segregation, regardless of whether they are sedentary or not. Member States should, as a minimum, ensure primary school completion. They should also widen access to quality early childhood education and care and reduce the number of early school leavers from secondary education pursuant to the Europe 2020 strategy. Roma youngsters should be strongly encouraged to participate also in secondary and tertiary education (European Commission, 2011).

\section{The Evolution of a Social Inclusion Policy Frame}

Social inclusion is a comparatively recent, broadly constructed policy area covering a number of discrete indicators. Essentially it requires that every citizen should be able to participate in society. This includes access to the labour market, adequate income support and access to quality services (European Council, 2010).

As citizens of Member States, Roma are of course entitled to take advantage of general social inclusion initiatives. On the other hand, a discrete Roma inclusion dialogue has emerged which can be traced back to 2005 when twelve south-eastern and central European states began to collaborate on best practice under the Decade of Roma Inclusion. The Decade's focus covers the same distinct indicators (health, unemployment, poverty and education) as more recent EU policy. Thus it may appear that Roma inclusion is merely one strand of social inclusion. Yet it may be countered that a specific "Roma inclusion" frame offers greater potential to address the underlying barriers to inclusion for Roma citizens, including structural discrimination and intersectionality. The focus on Roma enabled the Decade to identify overarching themes, including the elimination of discrimination and gender equality along with poverty reduction. The presence of discrimination as an obvious barrier to inclusion may not be so evident in a policy centred on socio-economic marginalisation uncoupled from ethnicity. This deficiency could be fatal to a project's success as inclusion for Roma across all the indicators depends, a priori, on the eradication of discrimination.

Representatives from twelve states identified national plans for the Decade of Roma Inclusion leading to a variety of projects funded by a combination of national governments, private donors and civil society (particularly the Open Society Foundations). The Decade's original lifespan is now coming to an end and there are ongoing discussions over how the work should be continued (Decade of Roma Inclusion, 2014a). Its activities have certainly raised the profile of Roma inclusion in the states concerned and its work can be viewed along with Roma migration as one of the catalysts for concerted EU action. Nevertheless, it has struggled to achieve tangible benefits for Roma communities. The Decade's own assessment of its overall performance identifies seven shortcomings (Decade of Roma Inclusion, 2013):

1) overly ambitious mission and vaguely defined priorities;

2) inadequate resourcing;

3) lack of an enforcement mechanism;

4) failure to address structural discrimination;

5) sporadic and inadequate monitoring, evaluation and reporting;

6) certain shortcomings in its structure; and

7) the existence of parallel initiatives (chiefly the EU Framework).

It will be obvious that several of these shortcomings relate to a power vacuum which prevents effective monitoring and enforcement, hampering meaningful progress. Absent external supervision, even proactive national governments will struggle to sell social inclusion initiatives to local authorities and electorates. Successful projects have thus tended to remain small-scale and short-term. One further difficulty making Decade projects a hard-sell is the specific, targeted focus on Roma inclusion. Many projects under the Decade 
adopted a targeted, exclusive approach which was often viewed with suspicion by non-Roma. If we accept that there is a great deal of animosity and mistrust characterising relations between Roma and non-Roma communities, this needs to be squarely confronted by inclusion projects. As Uzunova (2010, p. 386) argues "it is difficult to promote minority rights and nondiscrimination when the majority and minority have not even agreed to cooperate with each other."

By contrast, more successful projects adopted a mainstreaming approach. Of these, projects that made a deliberate effort to bring Roma and non-Roma together were assessed as offering the greatest potential for inclusion (Decade of Roma Inclusion, 2014b, p. 9). In respect of both these criticisms, the parallel initiatives of the EU provide an opportunity for significant progress.

Social inclusion is a comparatively new arena for the EU, as its competence in social policy was severely circumscribed until the Amsterdam Treaty in 1997. The Open Method of Coordination (OMC) places the obligation to address social inclusion on the national governments in a dialogical relationship (Armstrong, 2010, pp. 96-100; Barroso, 2008). As Armstrong (2010, p. 299) explains, it is the function of the OMC to assist states in identifying problems and appropriate solutions but they retain the ultimate responsibility for levels of poverty and social exclusion. He cautions against transferring the governance of social exclusion beyond the state to the EU level as an "impulse best resisted" (p. 300). Indeed, if norm diffusion is a necessary goal for Roma equality as has been argued, the support of national governments is essential. Daly (2008) is optimistic about the possibility of broader social policy measures being translated into meaningful national social policies under the OMC, pointing to the added legitimacy of a policy vision emanating from European political deliberations.

The European Platform Against Poverty and Social Exclusion is one of several initiatives under Europe 2020 which sees increased resources directed towards the eradication of poverty and social exclusion. A number of Common Principles on Roma Inclusion were presented at the first Platform meeting in April 2009. They were annexed to the Council conclusions of 8th June 2009 and comprise: 1) constructive, pragmatic and non-discriminatory policies, 2) explicit but not exclusive targeting, 3) inter-cultural approach, 4) aiming for the mainstream, 5) awareness of the gender dimension, 6) transfer of evidence-based policies, 7) use of EU instruments, 8) involvement of regional and local authorities, 9) involvement of civil society, and 10) active participation of Roma.

These principles now inform the work of both the EU and the United Nations when examining Roma inclusion (United Nations, n.d.). The Commission has requested that state action plans should pursue a target- ed approach in line with these Common Basic Principles, actively contributing to the social integration of Roma in mainstream society and eliminating segregation where it exists. Member States are, inter alia, asked to bear in mind the need to set achievable national goals for Roma integration. As a minimum, they should address the four Roma integration goals relating to access to education, employment, healthcare and housing. The plans should identify particularly disadvantaged micro-regions or segregated neighbourhoods and allocate sufficient funding from national budgets, which will be complemented, where appropriate, by international and EU funding. Further they should incorporate effective monitoring mechanisms and should be implemented in close cooperation and continuous dialogue with Roma civil society and local government. Finally, a national contact point should be established to coordinate the development and implementation of the strategy or, where relevant, rely on suitable existing administrative structures (European Commission, 2011).

The Europe 2020 agenda offers an opportunity to move Roma exclusion from the periphery of EU social policy into a central, mainstreamed focus on the eradication of poverty. Vermeersch (2014, p. 204) observes this development during the work of the Belgian presidency to the Council in $\mathbf{2 0 1 0}$ where the specific issue of child poverty in Roma communities moved from a marginal to a mainstream issue as part of the wider child poverty debate.

However, as a broad policy objective, social inclusion suffers from two essential flaws. Firstly, it tries to address too many issues and consequently obscures some of the most significant problems whilst throwing resources at schemes which will not be scaled-up enabling real change. The emphasis on national solutions may obscure the identification of common themes whilst simultaneously encouraging the generation of imprecise and woolly objectives that fail to reflect regional diversity.

The diversity of Roma populations certainly causes challenges for national governments seeking simple, uniform solutions (Klaus \& Marsh, 2014, p. 341). It is also likely that the challenges facing Roma communities in the Czech Republic are more akin to those experienced by Roma communities in Hungary, rather than those experienced by non-Roma Czechs. The identification of inter-state best (and worst) practice, drawing on the work of the Decade, certainly provides potential for positive outcomes but early indications have not been promising (European Council, 2013).

Secondly, the promotion of social inclusion through the open method of coordination can appear to suggest a lack of leadership, presenting states with an opportunity to avoid setting targets and allocating resources by passing the buck. A clear example of buckpassing can be seen with regard to the collective expul- 
sion of Roma migrants from France. The French government attempted to deflect criticism of the expulsions by passing the buck to the Romanian government (Crumley, 2010). The Romanian government in turn blamed the EU for failing to adopt a European strategy (Rostas in Guy, 2013; Sigona \& Vermeersch, 2012, p. 1190). Most of the time however, the buck stops with the Roma themselves as they are frequently labelled as the architects of their own exclusion (Stewart, 2012, pp. 6-7; O'Nions, 2011).

There are also difficulties relating to funding for social inclusion in terms of both access and accountability. It is understood that only a small percentage of EU structural funds available for Roma inclusion have actually been absorbed to that end (European Parliament, 2013; Open Society, 2011, p. 49). Moreover, there are some cases where funds have been allocated to projects which have actively contributed to social exclusion. An audit by the Hungarian education ministry revealed that some grants awarded to European accession states under the PHARE programme had been used to perpetuate school segregation (EMS, 2004). More recently, the European Commission has expressed concern over the misuse of structural funds allocated to the Czech Republic (Albert, 2011; Amnesty International, 2013).

Controversially it might be suggested that the principle beneficiaries of inclusion initiatives are civil society organisations. This can be borne out by the myriad of reports, initiatives and best-practice documents that rarely achieve meaningful change on the ground. This is not just a problem for civil society. An absence of coherence can similarly be viewed at the route of European policy by the Commission's failure to take the lessons learned under the Decade for Roma Inclusion as its starting point (Open Society, 2011, p. 8).

\section{Norm Diffusion through Legal Enforcement}

The evaluation reports of both the EU and the Decade action plans confirm that money is not the biggest obstacle to successful inclusion strategies. Whilst there are undoubtedly practical difficulties facing stakeholders when applying for funds, the biggest obstacle to achieving inclusion for Roma appears to be the prevailing hostility towards Roma at all levels of society.

There are acknowledged difficulties with the transfer of responsibility for Roma inclusion from the national government to the EU (Kovats, 2012; Gheorghe \& Kovats in Guy, 2013). But equally the accountability vacuum that exists at present seems unlikely to produce significant improvements in the near future. Indeed the EU may itself be accused of passing the buck by equating the primary responsibility of Member States with sole responsibility. It has been asserted that norm diffusion is the most effective way of addressing the challenges of structural discrimination and social exclusion (Allam, 2010; Vermeersch, 2012, p. 1203). With this in mind, it is argued that norm diffusion is best achieved through a combination of social policy initiatives and the enforcement of legal rules. Whilst legal norms may be viewed as subsidiary to social norms in the formation of societal attitudes and behaviour, law is often required to establish parameters for these norms where prevailing attitudes and practices are resistant to change. This is particularly the case when racial discrimination is endemic.

It is therefore significant to observe the European Parliament calling on the Commission to establish inclusion priorities which notably include the "full implementation of relevant legislation", including "appropriate sanctions for racially motivated crimes" (European Parliament, 2011). Yet an opportunity to link these priorities to the fundamental human rights and non-discrimination norms established by the ECtHR, the EU Charter and, most importantly, the Racial Equality Directive, has so far been missed. The Parliament recognised these concerns in December 2013 with a further resolution reflecting on the progress of the action plans (European Parliament, 2013). The Parliament calls on the Commission and Member States to ensure, inter alia, the implementation of the Racial Equality Directive and asks the Commission to take strong action, including enforcement proceedings, where fundamental rights are violated (para. 1,2). Their analysis of the implementation of Roma action plans reveals significant flaws and little progress by Member States despite the existence of underutilised EU funds.

The implementation of existing non-discrimination provisions is essential if there is to be any sustainable progress. There is of course a legal framework to tackle discrimination under EU law but there is growing concern amongst civil society actors that not enough is being done to address entrenched, structural discrimination that dictates the relationship between Roma and non-Roma (European Roma Policy Coalition and Decade of Roma Inclusion, 2012). As Gergely (2014) emphasises:

Without addressing the root causes of the spectrum of Roma rights violations and identifying concrete, measurable and effective actions to redress discrimination and to promote equality, complementing prohibitive anti-discrimination legislation, these policies will remain elusive.

\subsection{Non-Discrimination under EU Law}

According to the principle of subsidiarity, the EU should only act where the proposed action cannot be sufficiently achieved by Member States but can rather by its scale of effectiveness, be better achieved at a European level. The inability of several Member States to identify objectives and a clear strategy for Roma inte- 
gration has led the European institutions to adopt binding recommendations pursuant to Article 19(1) TFEU which enables appropriate action to combat discrimination. Frustrated by the lack of progress, the Commission proposed a recommendation in order to encourage states to meet their commitments (European Commission, 2013). The Council accepted this proposal and issued its Recommendation on Effective Roma Integration Measures in Member States (European Council, 2013). The recommendation draws on the Racial Equality Directive, the Charter of Fundamental Rights and the non-discrimination obligations in Treaty; explicitly embedding the legal norms into the Roma integration agenda.

The Racial Equality Directive does more than endorse formal equality. It will be recalled that it prohibits indirect discrimination and implicitly recognises that differential treatment for persons in substantially different situations may be required to ensure substantive equality. Specifically, special measures should be deployed in order to make reasonable accommodation for the specific needs of disadvantaged minority groups. In the context of education this could include pre-school support, free school transport and language proficiency classes (Henrard, 2010, p. 76). The Commission recommends that states "take effective measures to ensure equal treatment and full access of Roma boys and girls to quality and mainstream education" (European Commission, 2013, para. 1.3, 2.3a). However the Council are notably more cautious in their wording, recommending that "this goal COULD [my emphasis] be achieved by means of measures such as, inter alia, eliminating any school segregation" (1.3a) and "putting an end of any inappropriate placement of Roma pupils in special needs schools" (1.3b). The use of the word "Could" rather than "should" is regrettable and allows space for Member States to view de-segregation as an option rather than a necessity. On a more positive note, the reference in both documents to the Race Equality Directive, which is explicitly linked to the caselaw of the ECtHR, is a significant step forward.

The Charter of Fundamental Rights recognises that the rights contained therein should be interpreted in line with the European Convention on Human Rights (Art 52(3)). This could assist in establishing what Scheeck (2009, p. 17) describes as a "common supranational diplomacy". The Court of Justice has already adopted a proactive approach by considering the jurisprudence of the ECtHR when determining the effects of an EU Regulation on asylum policy. The decision in NS $v$ SSHD C411/10 (2012) was based on systemic failures in the Greek asylum system which breached the Charter of Fundamental Rights but the Court of Justice made reference to a case involving similar facts where a breach of Article 3 and 13 of the European Convention on Human Rights had been upheld (MSS v Belgium and Greece, 2011). Although the Court of Justice did not explicitly draw on the reasoning of the Strasbourg Court to the extent of the Advocate General, there is a tentative precedent for greater judicial activism when assessing compliance with EU obligations when there are existing rulings from the Strasbourg Court.

If social inclusion remains a policy umbrella without legally binding, defined targets, its success beyond the buzz-word will remain limited (Daly, 2008, pp. 1-19). Legal weight could be added however by a closer unity between the ECtHR judgements on Roma education and enforcement of the Racial Equality Directive. Linking legal obligations and policy discourses will undoubtedly ruffle a few feathers but it could pave a more effective path for Roma inclusion. As former EU President, Manuel Barroso, recognised at the third Roma summit in 2014, all players must respect European law, its principles and rules (European Commission, 2014a). The European Council have now recommended that the ECtHR judgements become a point of reference to assess the human rights compatibility of nondiscrimination provisions (European Council, 2013, para. 2.1). The recent decision to take enforcement action against the Czech Republic under the Racial Equality Directive sees the Commission drawing on Strasbourg case-law in assessing a Member State's commitment to its EU obligations (Cameron, 2014). Whilst the social inclusion agenda and the Framework do not impose legally binding obligations on states, where there is a failure to identify targets as part of an inclusion strategy, it may be legitimate to examine that state's commitment to related legal obligations. The infringement proceedings call into question the Czech Republic's compliance with Article 21(1) of the Charter of Fundamental Rights, which prohibits discrimination based on grounds including race or ethnic origin coupled with the Racial Equality Directive. The decision is explicitly informed by the ongoing failure of the Czech authorities to address the concerns of the Strasbourg Court in DH (2007).

\subsection{Lessons from Strasbourg Jurisprudence}

The series of cases heard by the ECtHR on the education of Roma in separate schools and classes generate far-reaching questions over the commitment of Member States to Roma inclusion and, consequently, the ability and capacity of the EU Framework to secure material progress (O'Nions, 2015).

The first case on segregated schooling of Roma pupils, $D H$ v Czech Republic, was decided by the ECtHR's Grand Chamber in 2007 (O'Nions, 2010). The case concerned 18 Roma pupils required to attend special schools for students with limited intellectual capacity. These schools followed a reduced curriculum which concentrated on practical rather than academic skills and, consequently, the pupils struggled to subsequently transfer to a mainstream educational environment. Inevitably the limited academic education resulted in pupils 
being less equipped to compete in the labour market.

The state argued that there was no intention to discriminate. The pupils had been identified following aptitude testing rather than ethnicity and the education provided was more appropriate for these pupils" needs and abilities. However, the absence of discriminatory intent could not belie the evidence that Roma pupils in Ostrava were 27 times more likely than non-Roma children to attend these schools ( $D H \vee$ Czech Republic, 2007, para. 17). The Grand Chamber reasoned that the aptitude tests were not culturally neutral, being conceived for the majority population without reference to the culture and socio-economic background of Roma pupils (White, 2011). The state's argument that Roma parents had consented to their child's placement was similarly rejected. In the face of entrenched discrimination, the signature of a parent on a pre-completed form could not be regarded as fully informed. Consequently the Czech Republic had violated the right to non-discrimination in Article 14 coupled with the right to education in Article 2 of Protocol 1.

The Court reached the same conclusion in Sampanis $v$ Greece (2008) where Roma pupils attending an integrated school received their teaching in a separate building. Following the judgement the pupils were moved from the annexe into a newly established primary school where the practice of segregation continued. This became the subject of a subsequent legal challenge by 140 Roma applicants in Sampani $v$ Greece (2012). The Chamber in Sampani recommended that the Greek authorities address the ongoing wrongs caused to these pupils through measures including adult education and second chance schools.

The Greek cases demonstrate the structural challenges facing advocates of Roma inclusion and validate the importance of full engagement with regional and local authorities (Sobotka \& Vermeersch, 2012). The Ministry of Education were aware that Roma pupils were still receiving a separate school experience but considered it both impractical and expensive to initiate integrated schooling. Indeed it was suggested that separation benefitted the Roma pupils who could be protected from the hostility of non-Roma parents. The town's mayor expressed wholehearted support for Roma segregation due to their "illegal activities" (Sampani, 2012, para. 25).

In the more finely balanced decision of Oršuš v Croatia (2010) a narrow majority of the Grand Chamber rejected the argument that separate, remedial primary classes would provide most benefit for Roma pupils. These pupils had poor command of the Croatian language and certainly required additional learning support but in the Court's view this could not justify a position of segregation which subjected Roma pupils to ongoing discrimination.

In the same year, the ECthR found a complaint concerning special classes in Hungarian schools, to be in- admissible due to the applicants" failure to exhaust domestic remedies. As with $\mathrm{DH}$, the students had received negative assessments of their intellectual potential following psychological evaluation. Rather than receiving special measures to remedy their position of comparative disadvantage, the students were taught by an unqualified teacher following a reduced curriculum. Three years later, a judgement was handed down in Horváth and Kiss v Hungary (2013) where two Roma men had been sent to schools for mentally impaired children having been diagnosed with mild learning difficulties. The Court accepted that Roma pupils were disproportionately consigned to these schools and that there no chance being able to sit the standard school examination. The reduced opportunities available in these schools left the men unable to pursue their chosen careers, limiting their life chances. The Court emphasised that, in light of persistent discrimination and the presence of cultural bias in past testing, states had a duty to avoid the perpetuation of discrimination disguised in allegedly neutral tests (para. 116).

The final case of Lavida $v$ Greece (2013) demonstrates that ECtHR judgements alone do not provide a sufficient catalyst for change in the presence of entrenched, structural discrimination (O'Nions, 2015). As noted the Greek authorities had already been criticised for their persistent refusal to take anti-segregation measures. The Greek Helsinki Monitor had twice written to the Ministry of Education raising concerns over segregation in primary schools in Sofades. Although the town had four schools, Roma pupils were attending a segregated school in a Roma housing estate. The Court rejected the government's contention that the Roma parents could have requested a transfer to an integrated school as this would place the responsibility for avoiding discrimination on the victims.

\subsubsection{Social Inclusion Framing in Strasbourg}

The need to consider integrated education as an aspect of social inclusion was not considered in $\mathrm{DH}$. This is perhaps unsurprising as the concept had yet to be developed as a central tenet of European social policy. Only Judge Jungwiert makes reference to inclusion and integration, both are given short shrift by reference to the work of Jean-Pierre Liégeois:

We must avoid over-use of vague terms ("emancipation", "autonomy", "integration", "inclusion", etc.) which mask reality, put things in abstract terms and have no functional value...officials often formulate complex questions and demand immediate answers, but such an approach leads only to empty promises or knee-jerk responses that assuage the electorate, or the liberal conscience, in the short term. (Judge Jungwiert in $\mathrm{DH} v \mathrm{Czech} \mathrm{Re}$ public, 2007, para. 19) 
In the Greek cases there is almost no reference to social inclusion. It does appear in a letter sent to the Greek education Ministry by the regional educational department where an explicit link is made between exclusion of Roma pupils and educational segregation. It does not however form an explicit part of the Court's reasoning (Lavida $v$ Greece, 2013). By the time of the decision in Horváth and Kiss, the relationship between social inclusion and education is starting to appear in the facts of the cases as they reflect national policy instruments. The Court therefore is compelled to have regard to the Hungarian Government's National Social Inclusion Strategy but again the specific theme of social inclusion is not explicit in the judgement (para. 71). Thus there is no specific social inclusion frame apparent in the judgements of the Strasbourg court.

Alternatively, Peroni and Timmer (2013) identify Roma as situated within a "vulnerable groups' paradigm" in the Court's judgements. As a vulnerable group, they should be afforded "special consideration" according to the Court in Horváth and Kiss (para. 102) and Oršuš and Others (para. 147-148). This special consideration could require initiatives to address obstacles to integrated schooling including the hostility of nonRoma parents, poor school attendance and the engagement of Roma parents (Danisi, 2011, p. 798).

Despite the identification of Roma as a vulnerable group, states are afforded a wide margin of appreciation when it comes to identifying the appropriate national response (Horvath and Kiss, para. 103). It might be suggested that the European institutions could learn from each other here as a growing European consensus on social inclusion and appropriate measures could assist the Strasbourg court in narrowing the margin to better protect the interests of Roma applicants. Although the Grand Chamber rejected a European consensus argument in Oršuš it is at least arguable that such a consensus has emerged in the intervening five years. If the Strasbourg Court is prepared to examine reports from civil society and the United Nations (as it does in Oršuš), it is even better placed to draw on the social policy experience of the EU and the Framework for Roma integration.

It is submitted that it would be preferable to forge consensus on Roma inclusion as an intrinsic part of the social inclusion narrative, rather than adopt a vulnerable group frame, when making a case for special measures. It has been noted that a focus on specific vulnerability carries an obvious danger in that it essentializes Roma as a problem minority characterised by disadvantage (Vermeersch, 2014, p. 216). The evaluation reports on the work of the Roma Decade reveal similar difficulties with Roma targeted projects which tend to be viewed with suspicion by non-Roma (Kocze et al., 2014). It is impossible to achieve social inclusion when such suspicion is not addressed as prevailing cultural and social norms remain unchallenged. In fact, targeted ac- tions that do not begin by addressing these norms are likely to deepen inequality and social exclusion.

\subsection{Lessons from the EU Framework}

Whilst EU accession led candidate countries to produce national policies to address the Roma minority, commitment was often superficial (Guy, 2012). Melanie Ram (2010) questions why the European Commission made improvements to the Roma situation a "precondition for membership" but for many observers this is over-stating conditionality. Whilst the EU certainly became more interested in the rights of minorities (including the Roma) following the Copenhagen meeting, the decision to allow full accession to candidate countries, notwithstanding grave concerns over their treatment of the Roma, is regrettable. As McGarry argues, once EU membership was secured, states were given the impression that they had done enough to improve the socio-economic situation of their Roma populations (2010, p. 149). Nothing could have been further from the truth.

The work of the Decade (in particular the Roma Education Fund) along with the endeavours of civil society has enabled significant progress on best practice. For example, it can be said with confidence that attendance at pre-school dramatically reduces the risk of pupils attending special schools or leaving education early (Brügemann, 2012, pp. 74, 78). It is also clear that early language support can have a considerable impact on the number of students assigned to special schools or classes on account of presumed intellectual impairment.

If research demonstrates best practice and structural funds are available for social inclusion, the question remains as to why so little progress has been made. The number of pupils attending special schools between 2004 and 2011 has remained the same in Romania and whilst it decreased slightly in Hungary there has been a marked increase in separate education in Croatia (Brügemann, 2012, p. 68). The former Council of Europe Commissioner for Human Rights, Thomas Hammarberg (2011), has reported that there had been no change in the Czech Republic since the decision in $\mathrm{DH}$. The same year a group of Czech educational advisors resigned in protest at the Government's failure to target de-segregation as a priority. Their resignation letter stated: "Under the existing leadership of the Education Ministry, it is becoming more and more obvious that inclusive education will remain mere rhetoric" (Amnesty International, 2012; Education International, 2011).

Analysis of the experience of migrant Roma attending British schools found that $85 \%$ of Czech Roma had previously attended a special school. Educational psychologists had since assessed these pupils and found that between 2 and $4 \%$ had special educational needs which required targeted learning support (Fremova, 
2011). These findings echo a report of the Czech school inspector in 2010 and the conclusions of the Czech Defender of Rights who found:

no legitimate discriminatory reasons by means of which it would be possible to justify the disproportionately high percentage of Roma children who are, in these circs, recommended for practical elementary schools (Bikár \& Albert, 2012; see also Czech Ombudsperson, 2012).

The European Council has acknowledged that progress under the Roma Integration Framework is insufficient. School segregation remains an enormous barrier to inclusion and it is extremely disappointing to note that it has not been viewed as a priority in national action plans (European Council, 2013). As with the Decade action plans, the indicators typically fall short of their potential to measure change (Brügemannn \& Kling, 2012, p. 26). The absence of valid ethnically disaggregated data in many countries has made it particularly problematic for states to adopt targets against which progress can be measured. Whilst this data collection is important (and is now being addressed) it cannot provide an excuse for the state's failure to commit to an integrated education as progress would be relatively easy to measure. Indeed, some of the national commitments appear little more than empty rhetoric; for example the Czech strategy pledges to increase "the accessibility and interlinking of early care services at local level in all required socially excluded Roma localities" (Brügemann, 2012). The "cut and paste culture" of some national action plans identified by Guy (2012) is indicative of casual indifference to the entire Roma inclusion objective.

There are several practical reasons why progress has been difficult to secure. This includes difficulties in accessing funding and the challenge of ensuring the engagement and participation of both Roma and nonRoma. School inclusion is often resisted by non-Roma parents who are deeply suspicious of Roma. This is seen clearly in the Greek cases where local officials were unwilling to facilitate inclusive education for fear of losing the support of their electorate. At the same time, Roma parents may prefer their children to be educated in a safe environment with similar pupils from the same background. Neither position is sustainable if we are to achieve progress in social inclusion as the active engagement of all stakeholders is fundamental.

By themselves a simple non-discrimination approach and even a special measures approach (as suggested by the ECtHR) will have limited impact where attitudes of mistrust and fear are deeply embedded. Both need to be complimented by equality mainstreaming (Kocze et al., 2014). For countries that have only recently adopted anti-discrimination legislation in response to the Racial Equality Directive this is a big ask. Rather like the United Kingdom in the late 1960's, discriminatory attitudes are deeply embedded in some of the newer EU states. These attitudes will not change because of ECtHR judgements or European Commission enforcement action. Neither are they likely to improve through specific Roma inclusion initiatives (as seen in the Decade). Thus an approach which brings together all sections of society, aiming to bridge the gap between the advantaged and disadvantaged (ie the social inclusion approach) may offer the greatest possibility for change. However, if it is to have any success then it must tackle discrimination in all its forms and it must secure active participation from the Roma community.

\section{Conclusion}

The Roma are Europe's largest ethnic minority and thus their integration must be a litmus test for social inclusion strategies. However, if we consider one key indicator of inclusion to be an integrated education, progress to date has been exiguous.

Daly (2008) contends that the EU has a "long history of trading on ambiguity". In the social policy context this ambiguity has enabled recalcitrant states to avoid committing to real progress towards Roma integration. This is particularly true for countries with relatively small Roma populations such as the Czech Republic. The European Commission has reported that the risk of social exclusion in the Czech Republic is the lowest in the EU (Sirovátka, 2012, p. 7). Yet this was the same year that Thomas Hammarberg referred to Czech Roma as "second class citizens" and civil society organisations recommended urgent action to overcome persistent segregation of Roma pupils (Amnesty International, 2013; Open Society, 2012).

Ten years ago, the European Roma Rights Centre predicted that soft law measures "may be necessary but not sufficient to tackle the particularly entrenched issues of racial discrimination against and systemic social exclusion of Roma and others regarded as "Gypsies" (ERRC, 2005). Yet to date there has been insufficient dialogue between European intergovernmental organizations. The EU Fundamental Rights Agency has reported on the implementation of the Racial Equality Directive but only makes passing reference to the jurisprudence of the ECtHR. In turn the ECtHR makes virtually no reference to the EU's social inclusion agenda in its judgements on discriminatory education.

This position may slowly be changing. The Czech government has recently reported that it will adopt an action plan to implement the judgement in $\mathrm{DH}$ (European Commission, 2014b). The Commission's infringement proceedings may well provide the impetus to adopt clear measurable targets. The carrot is provided by EU structural funds which should provide the Commission with renewed leverage and may help to en- 
gage local and regional stakeholders whose support is crucial for the success of inclusion initiatives (European Parliament, 2013; Guy, 2012).

Yet, the Croatian, Hungarian and Greek action plans ignore the need to prioritise de-segregation (European Commission, 2014b). The latest report for the European Council on Racism and Intolerance reveals that school segregation is worsening in Greece (as it is in Croatia) despite a national programme for the education of Roma children (ECRI, 2015). The degree of embedded discrimination in several EU Member States is an uncomfortable truth for an EU that prides itself on respect for the rule of law and the protection of minorities. Without concerted action to tackle discrimination and to encourage the development of legal and social norms at all levels of European society, social inclusion initiatives will continue to have no impact on Roma exclusion. The legal norms stem from the judgements of the ECtHR and the obligations in the Racial Equality Directive but they undoubtedly need to be strengthened and supported by enforcement action. The social norms will come from an equality mainstreaming approach which brings Roma and non-Roma together, to tackle inequality and social exclusion for the benefit of all European citizens.

\section{Conflict of Interests}

The author declares no conflict of interests.

\section{References}

Albert, G. (2011). Commentary: Roma association forum calls on EU to halt structural funds for Czech Republic, Romea.CZ. Retrieved from http://www. romea.cz/en/news/czech/commentary-romaassociation-forum-calls-on-eu-to-halt-structuralfunds-for-czech-republic

Allam, N. (2010). Stateless Roma in Europe: A case study of European migration, citizenship and identity policies. Paper presented at the 8th ECSA-C Biennial Conference "Wither Europe?" Victoria, BC, 30th April 2010.

Amnesty International. (2012). Five more years of injustice: Segregated education of Roma in the Czech Republic. Brussels: Amnesty International.

Amnesty International. (2013). The Czech Republic's discriminatory treatment of Roma breaches EU Race Directive. Brussels: Amnesty International.

Armstrong, K. (2010). Governing social inclusion. Oxford: OUP

Barroso, J. M. (2008). Speech at European Roma Summit, Brussels, $16^{\text {th }}$ Sept 2008.

Bikár, F., \& Albert, G. (2012). Czech ombudsman: Research confirms indirect discrimination of Romani pupils, Romea.CZ. Retrieved from http://www. romea.cz/en/news/czech/czech-ombudsman- research-confirms-indirect-discrimination-ofromani-pupils

Brügemann, C. (2012). Roma education in comparative perspective. Findings from the Ivanov/World Bank/EC regional Roma survey 2011. Roma Inclusion Working Papers. Bratislava: UNDP.

Brügemann, C., \& Kling, J. (2012). Measuring adults? Education indicators in Roma integration strategies. Development and Transition, 19, 26-28.

Cameron, R. (2014). Roma complain of Czech school segregation. $B B C$ News, $24^{\text {th }}$ Oct.

Crumley, B. (2010). A defiant France steps up deportation of Roma. Time, $1^{\text {st }}$ Sept 2010.

Czech Ombudsperson. (2012). Report of the Public Defender of Rights (Ombudsperson) on the ethnic composition of pupils in the former special schools. Retrieved from http://www.ochrance.cz/fileadmin/ user_upload/DISKRIMINACE/Vyzkum/Vyzkum_ skoly-zprava.pdf

Daly, M. (2008). Whither EU social policy? An account and assessment of developments in the lisbon social inclusion process. Journal of Social Policy, 37(1), 1-19.

Danisi, C. (2011). How far can the European Court of Human Rights go in the fight against discrimination? Defining new standards in its nondiscrimination jurisprudence. International Journal of Constitutional Law, 9(4), 793.

Decade of Roma Inclusion. (2013). To Be or Not to be? Roma decade after 2015. Retrieved from http:// www.romadecade.org/cms/upload/file/9283_file1_t o-be-or-not-to-be-roma-decade-after-2015.pdf

Decade of Roma Inclusion. (2014a). Conclusion from the Decade future meeting in Bucharest, Feb $20^{\text {th }}$ 2014. Retrieved from http://www.romadecade.org/ cms/upload/file/9738_file3_conclusions-from-thedecade-future-meeting-in-bucharest.pdf

Decade of Roma Inclusion. (2014b). Decade intelligence report. Factors for success or failure of Roma inclusion projects, Decade Secretariat, May 2014. Budapest: Secretariat, Decade of Roma Inclusion.

DH v Czech Republic. (2007). ECtHR App 57325/00.

ECRI (2015). Report on Greece. Fifth monitoring cycle, Feb 2015. Strasbourg: Council of Europe.

Education International. (2011). Czech Republic: Inclusive education experts resign at government inaction, $3^{\text {rd }}$ June. Retrieved from http://www.eiie.org/en/news/news_details/1827

EMS. (2004). European Commission DirectorateGeneral Enlargement review of the European Union Phare assistance to Roma minorities (Dec 2004 Report ZZ/MIN/03082, 09 December 2004). Brussels: European Commission.

ERRC. (2005). European Roma Rights Centre submission to the European Commission concerning implementation of the Race Equality Directive in the Czech Republic, Hungary, Poland, Romania, and Slovakia, 
July 2005 Budapest: ERRC.

EU Fundamental Rights Agency. (2011). The Racial Equality Directive: Application and challenges. Vienna: EU Fundamental Rights Agency.

European Commission. (2011). Communication from the Commission to the European Parliament, the Council, the European Economic and Social Committee and the Committee of the Regions an EU framework for national Roma integration strategies up to 2020 (COM(2011) 173 Final). Brussels: European Commission.

European Commission. (2013). Proposal for a Council recommendation on effective Roma integration measures in Member States (Brussels 26.6.2013 COM (2013) 460 final). Brussels: European Commission.

European Commission. (2014a). Speech by President Barroso at the European Roma Summit, Brussels $4^{\text {th }}$ April 2014 Brussels: European Commission Press Release.

European Commission. (2014b). Report on the implementation of the EU Framework for National Roma Integration Strategies, Brussels $2^{\text {nd }}$ April 2014 COM (2014) 209 final. Brussels: European Commission.

European Commission. (2014c). Joint report on the application of Council Directive 2000/43/EC Of 29 June 2000 implementing The Principle of Equal Treatment Between Persons Irrespective Of Racial Or Ethnic Origin ("racial Equality Directive") And of Council Directive 2000/78/EC Of 27 November 2000 Establishing A General Framework For Equal Treatment In Employment And Occupation ("Employment Equality Directive"), 17 $7^{\text {th }}$ January 2014 COM (2014) 2 Final. Brussels: European Commission.

European Council. (2000). Council Directive 2000/43/EC of 29 June 2000 Implementing the principle of equal treatment between persons irrespective of racial or ethnic origin Official Journal L 180 19.7.2000, pp. 22-26. Brussels: European Council.

European Council. (2009). Council conclusions of 12 may 2009 on a strategic framework for European cooperation in education and training. Official Journal C 119 28.5.2009, pp. 2-10. Brussels: European Council.

European Council. (2010). Draft Report on social protection and social inclusion Brussels, 15 ${ }^{\text {th }}$ Feb 2010. Brussels: European Council.

European Council. (2012). Consolidated Version of the Treaty on the Functioning of the EU Official Journal C326/01 26.10.2012. Brussels: European Council.

European Council. (2013). Recommendation on Effective Roma Integration Measures in Member States, Brussels 9 and $10^{\text {th }}$ Dec 2013. Brussels: European Council.

European Parliament. (2011). Resolution on the EU strategy on Roma inclusion. Official Journal C199 E, 7.7.2012 p112. Strasbourg: European Parliament.
European Parliament. (2013). Resolution on the progress made in the implementation of the National Roma Integration Strategies. 12 ${ }^{\text {th }}$ Dec 2013 P7_TAProv (2013)0594. Strasbourg: European Parliament.

European Roma Policy Coalition and Decade of Roma Inclusion. (2012). document prepared at the preparatory meeting of civil society representatives Brussels, 21 ${ }^{\text {st }}$ March 2012. Brussels: European Commission.

Fremova, L. (2011). From segregation to inclusion. Roma pupils in the UK a pilot research project Suffolk: Equality.

Gergely, D. (2014). Fighting discrimination and promoting equality in the context of the Roma inclusion policies in Europe. Retrieved from http://www.errc. org/popup-article-view.php?article_id $=4238$

Guy, W. (2012). Roma inclusion at the crossroads: can the lessons from PHARE be learned? In ERRC Roma Rights 2011: Funding Roma rights. Challenges and prospects. Budapest, ERRC.

Guy, W. (Ed.) (2013). From victimhood to citizenship: The path of Roma integration. Budapest: Pakiv European Roma Fund.

Hammarberg, T. (2011). Council of Europe Rights commissioner, Reported no changes since DH in 2010. CommDH (2011)3, $3^{\text {rd }}$ March 2011. Strasbourg: Commissioner for Human Rights.

Henrard, K. (2010). An EU perspective on new versus traditional minorities: On semi-inclusive socioeconomic integration and expanding visions of "European" culture and identity. Columbia Journal of European Law, 17, 57.

Horváth and Kiss v Hungary. (2013). ECtHR App 11146/11.

Klaus, S., \& Marsh, A (2014). A special challenge for Europe: The inclusion Of Roma children in early years education and care. European Early Childhood Research Journals, 22(3), 336-346.

Kocze, A., Kullman, A., Scharle, A., Szendrey, O., Teller, N., \& Zentai, V. (2014). Programming the structural funds for Roma inclusion 2014-2020. Budapest: Open Society Foundations.

Kovats, M. (2012). The EU's Roma role. Open Democracy, 11th May.

Lavida v Greece. (2013). EctHR App. 7973/10.

McGarry, A. (2010). Who speaks for Roma? Political representation of a transnational minority New York: Continuum.

MSS $v$ Belgium and Greece. (2011). ECtHR App 30696/09.

NS v SSHD. (2012). C 411/10.

O'Nions, H. (2011). Roma expulsions and discrimination: The elephant in Brussels. European Journal of Migration and the Law, 13(4), 361-388.

O'Nions, H. (2015). Warehouses and window-dressing. Journal of International Education Research and Development Education, 38(1), 4-10. 
Open Society. (2011). Beyond rhetoric: Roma integration roadmap for 2020. Budapest: Open Society.

Open Society. (2012). Failing another generation. The travesty of Roma education in the Czech Republic. New York: Open Society.

Oršuš v Croatia. (2010). ECtHR 15766/03

Peroni, L., \& Timmer, A. (2013). Vulnerable groups: The promise of an emerging concept in European human rights convention law. International Journal of Constitutional Law, 11(4), 1056.

Ram, M. (2010). Interests, norms and advocacy: Explaining the emergence of the Roma onto the EU's agenda. Ethnopolitics, 9(2), 197-217.

Sampani and Others $v$ Greece. (2012). ECtHR App. 59608/09, 11 $1^{\text {th }}$ December, 2012.

Sampanis $v$ Greece. (2008). ECtHR App. 32526/05, $5^{\text {th }}$ June 2008.

Scheeck, L. (2009). The diplomacy of European judicial networks in times of constitutional crisis. In F. Snyder \& I. Maher (Eds.), The evolution of the European courts and integration through human rights. Change and continuity (pp 17-36) Brussels: Bruylant.

Sigona, N., \& Vermeersch, P. (2012). The Roma in the new EU: Policies, frames and everyday experiences. Journal of Ethic and Migration Studies, 38(8), 11891193.

Sirovátka, T. (2012). Assessment of the implementation of the European Commission recommendation on active inclusion. A study of national policies. Czech Republic. Brussels: EU, Network of Independent Experts on Social Inclusion, European Commission.
Sobotka, E., \& Vermeersch, P. (2012). Governing human rights and Roma inclusion: Can the EU be a catalyst for local social change? $H R Q, 34(3), 800-$ 822.

Stewart, M. (2012). The Gypsy "menace": Populism and the new anti-Gypsy politics. London: Hurst.

UNESCO. (1960). Convention against Discrimination in Education $14^{\text {th }}$ Dec. 1960. Paris: UNESCO.

United Nations. (n.d.). The role of the United Nations in advancing Roma inclusion. New York: UN.

United Nations. (1965). International Convention on the Elimination of All Forms of Racial Discrimination, UN General Assembly resolution 2106 (XX) of 21 December 1965. New York: United Nations.

United Nations. (1989). Convention on the Rights of the Child. UN General Assembly Resolution 44/25 of 20 November 1989. New York: United Nations.

Uzunova, I. (2010). Roma integration in Europe: Why minority rights are failing. Arizona Journal of International and Comparative Law, 27(1), 283-323.

Vermeersch, P. (2012). Reframing the Roma: EU initiatives and the politics of reinterpretation. Journal of Ethnic and Migration Studies, 38(8), 1195-1212.

Vermeersch, P. (2014). The European Union and the Roma: An analysis of recent institutional and policy developments. In T. Malloy (Ed.), Minority governance in and beyond Europe (pp. 199-222). Koninklijke: Brill.

White, J. (2011). Entry testing as a factor in overrepresentation of Romani children in special education. Budapest: Roma Education Fund.

\section{About the Author}

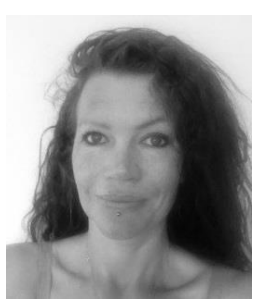

\section{Dr. Helen O'Nions}

Helen O'Nions is a senior lecturer in Law at Nottingham Trent University. In 2000 she completed her $\mathrm{PhD}$ at the University of Leicester critically examining the legal position of human rights in Europe and the application of minority rights provisions to the Roma. She is the author of "Minority Rights Protection in International Law: The Roma of Europe" (2007) and "Asylum: A Right Denied" (2014). She is a founding member of Nottingham Law School's Centre for Conflict, Rights and Justice and editor of the Nottingham Law Journal. 